\title{
GASTRONOMIC EVENTS IN THE FUNCTION OF CREATING A BRAND OF A TOURIST DESTINATION: THE EXAMPLE OF STRUDEL FESTIVAL IN DOLOVO
}

\author{
Slobodan Čavićl, Marija Mandarić2, Dejan Sekulić3 \\ *Corresponding author E-mail: slobodan.cavic@vhs.edu.rs
}

A R T I C L E I N F O
Original Article
Received: 05 April 2021
Accepted: 28 August 2021
doi:10.5937/ekoPolj2103659C
UDC 338.48-6:641]:338.48-
611(497.11 Dolovo)

Keywords:

strudel, brand, gastronomic events, tourist destinations

JEL: M31, Z32, L66, Q18

\begin{abstract}
A B S T R A C T
Gastronomic events in recent years represent a very significant segment for the development of tourism. There are numerous events traditionally taking place in Vojvodina. Each of these events is unique and represents a rich variety of customs, culture and traditions. The authentic gastronomic offer, which is promoted through these events, is an important segment for creating a brand of a particular place and tourist destination. The aim of this study is to investigate the recognizability of the Strudel festival in Dolovo, as well as the authenticity of this gastronomic event, in terms of creating a brand of the tourist destination. The research was carried out using the survey method, through a questionnaire, on a sample of 150 respondents. Based on the collected data, using statistical methods of binary logistic regression, chi-square and Fisher's test, the analysis was performed and the results were presented. The results of the research show that the Strudel festival in Dolovo and its brand - strudels - have a high level of recognizability among visitors. However, the Strudel festival in Dolovo should be promoted more intensively, as it is currently recognized locally, and has the potential to attract more tourists.
\end{abstract}

(C) 2021 EA. All rights reserved.

1 Slobodan Čavić, Ph.D. candidate, University of Kragujevac, Faculty of Hotel Management and Tourism in Vrnjačka Banja,Vojvođanska 5a, 36210 Vrnjačka Banja, Serbia, Phone: +381643057228, E-mail: slobodan.cavic@vhs.edu.rs, ORCID ID (https://orcid.org/00000001-9414-1362)

2 Marija Mandarić, Ph.D. Associate Professor, University of Kragujevac, Faculty of Hotel Management and Tourism in Vrnjačka Banja, Vojvođanska 5a, 36210 Vrnjačka Banja, Serbia, Phone: +381642590099, E-mail: mmandaric@kg.ac.rs, ORCID ID (https://orcid. org/0000-0002-8504-3944)

3 Dejan Sekulić, Ph.D. Assistant Professor, University of Kragujevac, Faculty of Hotel Management and Tourism in Vrnjačka Banja, Vojvođanska 5a, 36210 Vrnjačka Banja, Serbia, Phone: +38162602902, E-mail: dejan.sekulic@,kg.ac.rs, ORCID ID (https://orcid. org/0000-0002-3816-3679) 


\section{Introduction}

In recent years, tourism has an important role in the economic development of every country.

Event tourism has developed greatly giving rise to a stronger development of tourism as an economic activity, and since the early 1980s it has been regarded as a separate industry. The event industry has been defined as "the systematic planning, development and marketing of festivals and special events, catalyst and image builder" (Getz \& Wicks, 1993).

Event tourism is an important motivator for travelling and one of the fastest growing segments of the tourism industry. It is the result of the potential of the event to raise the level of tourist attractiveness, media coverage and promotion of the site and destination for future visitors (Backman et al., 1995).

Gastronomic tourism can be defined as "visitation to primary or secondary food producers, food festivals, catering facilities for food production and service and certain destinations for tasting and experiencing the attributes of regional specialties, where food is the primary motive for travel" (Hall \& Mitchell, 1998). It can also be defined as "the activity of research and discovery of different cultures and histories through food, which can influence the formation of unforgettable experiences of tourists" (Long, 2004). Tourists are increasingly travelling to visit a particular destination, and the reason for this might be exactly the local specialties that are authentic and characteristic of the area or region. Gastronomic tourism can be a competitive advantage, as well as a unique feature in the branding of a particular country or region. A clearly defined gastronomic identity and heritage can be exploited in crucial processes of differentiation, helping to convey a unique sense of a tourist destination (Fox, 2007). Over the years, we have witnessed a growing number of events focusing on presenting the gastronomy of a certain area of the country. These are exactly where the opportunities for attracting a larger number of tourists, domestic as well as foreign, can be found. According to Stojanović et al. (2018), "through the affirmation of authentic food and beverages, any region can become a significant tourist destination, and one of the means to present and promote them can be through gastronomic events".

\section{Gastronomic events}

The research on food tourism, also known as culinary, gastronomic or gourmet tourism, has become increasingly important in recent years (Hall et al., 2003),which has lead to food-related events creating their own niche market and developing their own specialized organizations, thus taking on an important role in tourism as well. As stated by Wargenau \& Che (2006), "the number of gastronomic events worldwide is constantly growing along with the interest in gastronomic tourism, representing a very interesting form of recreation and tourist attraction".

Show, festival, event, performance are simply different conceptual nuances that signify "a period of a certain program with a specific content that is attractive for tourist visits" 
(Bjelac \& Ćurčić, 2007). Event is unique due to the interaction that exists between the place where it is held and the visitors. Its appeal lies precisely in the fact that every gastronomic event is unique and that the visitor has to be physically present in order to be able to fully enjoy the event.Numerous researches show that they have not been aptly promoted, and they can give rise to the advancement of the economy, the region and the country as a whole.

Jovanović (2015) argues that "events or organized events, as a reflection of modern tourism, with regard to culture (music festivals, concerts, exhibitions, contests etc.), sports (regattas, water-skiing, etc.), tradition (carnivals, gastronomy, folklore, etc.), are gaining more importance in modern tourism". Over the past decade, events have become increasingly important for the growth of tourist traffic and the improvement of economic effects achieved through tourist activities; these events, due to their quality as well as quantity give special value to tourist destinations on both domestic and international tourist market (Stevanović \& Malinić, 2016). Gastronomic events can serve as a means of promotion of the destination as a destination of gastronomic tourism. They can be used for the presentation but also the preservation of authentic food and drinks of a particular place, which are prepared in the traditional way. Čavić \& Stojanović (2018), suggest that "every region that abounds in authentic gastronomic products should be represented and placed in the overall tourist offer of a certain country".

Gastronomic events reflect a special link between food, beverages, tourist events and travel. Authentic food at events is an instrument of connecting with visitors who, along with taking part in cultural activities, try gastronomic specialties distinctive of an area and become acquainted with the culture and traditions of the locals (Čavić \& Mandarić, 2021). Gastronomic events can influence the creation of the awareness among consumers of brands they did not even know existed. The existence of awareness of certain gastronomic products and tourist destinations can influence visitors to prefer events of which they have more knowledge. Serbia has a rich and varied cuisine, which abounds in traditional specialties. In recent years, manufacturers have shown a strong tendency to protect products with geographical origin and invest in developing their brand. One of the ways to achieve that is through gastronomic events in Serbia. They attract and gather numerous individuals, who come to taste food and drinks, to observe or take an active part in the preparation of food and beverage, and to be entertained through the supporting cultural and artistic program or competition. Such events are usually held once a year in the same period, as they represent a kind of tradition.

\section{Events as a factor of visits to a tourist destination}

On the territory of the Republic of Serbia, there is a large number of traditional and authentic gastronomic products offered to tourists. Every year the number of events is increasing, and their main goal is to put on display the gastronomy of a certain tourist destination. Through the affirmation and promotion of events where authentic food and beverages are presented, every place or region can be turned into a noteworthy tourist destination. Events that exhibited gastronomic products used to be part of fairs and festivals, but this 
began to change at the end of the last century. The creation of the so-called gastronomic tourism started through these unique events. Gastronomic events contribute to the national economy as the sale of gastronomic products and beverages generates significant material resources. Certain gastronomic products and beverages have become a brand both of the region and the country, and are internationally recognized (Stojanović, 2017). Mandarić \& Stamenković (2017), state that "the attendance of a tourist destination and branding, through the development of event tourism, contributes to strengthening the competitive position of the destination itself, makes it easier to overcome the geographical distance, attracting new and retaining the existing tourists and visitors to the destination, while achieving favourable economic effects".

Furthermore, Stojanović et al. (2020), observe that "gastronomic events held in rural areas have a great promotional and entrepreneurial potential, as the gastronomic products from these events could be offered to local restaurants, as well as to retail chains, which would positively affect the revitalization of the rural area of a particular tourist destination". According to the "Strategy for the development of tourism in Serbia for the period 2016-2025", events are positioned in the second place as a tourist product of special importance for the development of tourism. Furthermore, this document positions gastronomic tourism among the common motives of tourists to travel to a certain place (http://mtt.gov.rs/download/3/strategija.pdf).

\section{Branding of a destination and gastronomic event}

Strategic brand management is a concept that includes the design and implementation of marketing activities aimed at building and managing brands. Branded products and services have characteristics that allow the consumer to differentiate them from other similar products and services. A branding strategy achieves an original or unique recognition of a product, service, person or group of people, concept, business model, event, company or institution and differentiates the offer in relation to the competition.

Holders of the brand can be people, objects, geographical destination, goods, services and others (Mandarić, 2016). Strong brands have become a source of market differentiation and sustainable competitive advantages and that's why brand management principles has greater application and geographical destinations (Jojić Novakovic \& Mandaric, 2019). Branding of a destination provides continuous promotion of a country's tourism and increases the attractiveness of its tourism products. According to Veljković (2010), a destination brand can be defined "as a name, symbol, logo, word and / or other graphics that serve to identify and distinguish a destination from competitors. It promises the potential visitors an unforgettable experience of traveling to a particular destination; furthermore, it serves to consolidate and solidify the memories of beautiful experiences of those who have already been there". Modern brand management also incorporates the emotional component of experiencing a brand, which supports connecting the experiences of visitors to an event with the development of the destination brand (Mandarić, 2016). Various manifestations and gastronomic events can be the reason for a certain place to become the destination that will be chosen by both domestic 
and foreign tourists. The brand becomes a key factor because it gives an additional value and a promise to potential tourists or visitors that they will experience something special in the destination, which is worth a visit (Perić \& Mandarić, 2020). So, branding of a gastronomic event affect the perception and creation of the image of the tourist destination and it means that the recognizability of a gastronomic event brings potential tourists to a particular destination.

Significant qualitative changes have made the services sector more competitive in recent years. Professional branding in the service sector has contributed to standardization in service delivery. By building a brand, the consumer is able to more easily see the distinctive advantage in providing services to a particular company over its competitors. That is why more and more original, affirmative and driving ideas are the subject of branding. Original ideas can become manifestations that are characterized by specific slogans, symbols, concepts, etc. Organized events that attract a lot of media attention and a significant number of visitors are often branded. Numerous festivals and gastronomic events in our country are branded and their attractiveness attracts an increasing number of domestic and foreign guests from year to year. These are events suitable for placing marketing ideas and projects, and enable the transfer and spillover of the image to other strong brands (Mandarić, 2016). Creating unique and positive experiences represents a new development phase in marketing and branding. Gastronomic events have great potential to create authentic experiences for visitors and are in a position to create a strong brand as well.

\section{The distinctive features of the gastronomical offer of Vojvodina}

The gastronomical offer of Vojvodina includes authentic food and drinks, which are popularized and marketed through various gastronomic events, as well as through specific catering facilities such as isolated farms (granges), chardas, ethno restaurants, households. There are 27 nations living in the area of Vojvodina, with different customs, culture and traditions in everyday life. Each of them has its own authentic specialties, which make the gastronomic offer of Vojvodina a rich treasury of various gastronomic products. The number of events is large, and they include numerous distinctive features of an area and the people who live there. The event tourism of Vojvodina has been developing based on different economic activities, customs, beliefs, traditions, habits, in an ethnically and religiously heterogeneous area.That is how numerous festivals, events, fairs, exhibitions, gatherings and congresses were created, and with their programs and offer, they represent a significant tourist potential in the overall offer of Vojvodina and Serbia.They are different forms of performance, which contain certain artistic, entertaining, educational, cultural and other similar values important for Vojvodina.

Gastronomic events, which are frequently held in rural areas, are genuine protectors of tradition and perfectly present the typical food and the lifestyle of a particular nation. The number of international gastronomic events is small, but they still exist, which is important as the local food and beverages are presented to the tourists who encounter 
the Serbian tradition for the first time. The number of events is Serbia is growing from year to year, and therefore it is assumed that the number of events important for the development of tourism will be even bigger in the future (Stanišić et al, 2018). As argued by Mandarić et al. (2017), "traditional gastronomic products, due to their character, quality and heritage, may become a regional brand and also promote the region as a unique destination of rural tourism".

\section{Gastronomic event 'Strudel Festival in Dolovo' and strudel as the trademark of the event}

Every autumn, always on the first Saturday in September, the event called "Dolovačka Strudlijada" (the Strudel festival in Dolovo) is held in the village of Dolovo near Pančevo, organized by the Women's association "Dolovke". The event lasts for four days. On the first and the second day of the event a promotion is held in the city of Pančevo, on the third day is the opening of the exhibition of handicrafts of women from the association and various workshops, and the fourth day is when the main part of the event is held in the village of Dolovo (https:/www.manifestacije.com).

The women's association in Dolovo was founded in 1977. In 2010 it was registered and has ever since been known under the name Women's association "Dolovke". With a new modern approach in its activities it has become one of the most active women's associations in the city of Pančevo. The association has about 50 members working on the preservation of Serbian traditions, organizing cultural and entertainment events, educating and encouraging women to take part in community service and charities. Accordingly, the association has numerous programs and activities not only in Dolovo, but throughout Serbia, where they present their creative work and their potential. The fact that the association has existed for such a long time is a rare case in our environment, especially taking into account the number of members. One of the goals of the Asociation "Dolovke" is the popularization of traditional dishes and cakes, and especially strudel as a local specialty. Throughout the year, the association promotes the event "Strudel festival of Dolovo", which is the brand of this region, at various events and fairs in Serbia. The women from the association represent themselves, their village as well as the city of Pančevo in the best way through their activities and work. They are a good example of how much can be achieved by joining forces. Part of the activities that the association realizes is through workshops, forums, conferences, various forms of education, visits to cultural and historical sites, charity work, supporting not only the women who are members of the association but other women as well to become stronger and take an active part in the life of the rural community.Through the work and commitment of all the members, this important event and its brand - the strudel - are preserved and fostered. The association participated in furnishing their premises and opened the Ethno Room in Dolovo, with authentic furniture and houseware, in order to show the right way to preserve the culture, traditions and customs of the region they live in (https://www.manifestacije.com). 
In this picturesque place on the slopes of the Deliblato Sandsit is almost impossible to find a woman who does not know how to prepare this famous cake. The German women from Westphalia and Bavaria brought this skill to Dolovo, anhd the local women have brought this cake to perfection. They have preserved the recipe for this cake, passing it from generation to generation in order to preserve the tradition. The tradition of making strudel in Banat and Vojvodina has been present for a very long time. Sunday lunch includes a cake prepared traditionally here, and that is strudel. The Dolovo Strudel Festival has become well-known not only in the area of Pančevo and South Banat, but also in the whole of Vojvodina and Serbia. The strudel prepared in Dolovo has become a trademark of this event and of the whole place, as all the guests coming here say that such strudels can be tasted only in Dolovo. Recognizability and authenticity are the first words that come to mind when talking about Dolovo strudel, and therefore it can be said with certainty that it is the real brand of this event and this place (https://www. manifestacije.com).

The Dolovo Strudel Festival has received numerous awards, certificates and trophies so far and, most importantly, it has been branded with a trademark obtained from the Intellectual Property Office of the Republic of Serbia (http://reg.zis.gov.rs/regis/detail. php? entity $=$ mark \&lang $=$ sr\&file nbr $=2010 \quad 00001199$ ). All this indicates that this event is extremely important for the preservation of the intangible cultural heritage of both Vojvodina and Serbia. This gastronomic event has been held for 20 years continuously, indicating that there is great interest and desire to include this traditional event and its brand - strudel - in the typical gastronomic offer of Vojvodina not only to domestic, but also to foreign tourists. The survey was conducted with the aim of better understanding of this event, in order to reach certain conclusions and recommendations for its better promotion and affirmation at a higher level than the present one.

\section{Materials and methods}

During the setting of the goals of the work and the structure of the research, the aim was to point out the importance of gastronomic events, with special attention being paid to one particular event - the Dolovo Strudel Festival. The research was carried out during the event in September 2019, using a questionnaire. The sample of the respondents consisted of 150 visitors, with intentional purposive sampling.

The survey questionnaire consisted of 10 open-ended and 12 closed-ended questions, clearly and precisely defined, in order to reach appropriate conclusions. The first part of the questionnaire referred to the socio-demographic characteristics of the respondents such as gender, age, education, as well as the place of residence. The second part referred to the knowledge the respondents had of the event itself, how they had learned about the event, what they thought was authentic, whether they found the program and the competition part interesting or not, what they were going to take from the event as a souvenir, what was the reason for coming and whether they were members of an association or visitors. The third part of the questionnaire referred to the Dolovo strudel itself, as the brand of the event. The sample included the members of numerous 
associations present at the event, as well as visitors. The respondents were informed that participation in the research was anonymous and voluntary, and that the results would be used exclusively for scientific research purposes. All survey data were valid.

Descriptive statistical measures - frequencies and percentages - were used to describe the research sample. All the questions used are categorical questions. The method used was that of binary logistic regression. In order to examine the effect of several variables on one, logistic regression was used. The dependent variable is dichotomous, and therefore binary regression was used. The Chi-square and Fisher's test were used to examine the differences in statistical processing of the data. The chi-square test was used to examine differences in authenticity and brand in individual questions. Statistical package used was SPSS 22.0 ("Statistical Package for Social Sciences for Windows 22.0”) (Leech et al., 2005, Pallant, 2011, Sheskin, 2004).

\section{Results and discussion}

The demographic characteristics of the respondents included gender, age and education. The results of the research show that the event was attended by a larger number of women (121 - 80.07\%) compared to men (29 - 19.3\%). In terms of their age, most respondents are over 50 years old (85-56.7\%), then from 36 to 50 (38 $-25.3 \%)$ and up to $35(27-18.0 \%)$. As for their level of education, the number of respondents who completed elementary and high school is the largest (94-62.7\%), then college or university $(47-31.3 \%)$, and the number of those holding a master's degree or $\mathrm{PhD}$ is the smallest $(9-6.0 \%)$.

Table 1. shows the respondents' place of residence.

Table 1. Respondents' place of residence

\begin{tabular}{|lcc|}
\hline Variables & Frequency & Percentage \\
\hline Respondent's place of residence & & 26,7 \\
\hline Pančevo & 40 & 33,3 \\
\hline Dolovo & 50 & 10,0 \\
\hline Belgrade & 15 & 4,0 \\
\hline Kačarevo & 6 & 4,7 \\
\hline Kovin & 7 & 5,3 \\
\hline Starčevo & 8 & 4,0 \\
\hline Bavanište & 6 & 4,7 \\
\hline Omoljica & 7 & 3,3 \\
\hline Novi Sad & 5 & 4,0 \\
\hline Ivanovo & 6 & \\
\hline
\end{tabular}

Source: Author's calculation based on SPSS 22.0

Table 1. shows the answer to the question 'What is the respondent's place of residence?'. In the sample of 150 respondents the largest number are from Dolovo $50(33.3 \%)$, then from Pančevo 40 (26.7\%), Belgrade 15 (10\%)and a considerably smaller number from 
other places. The results show that the event is mostly attended by the local population of Dolovo and the city of Pančevo, whereas the number of visitors from other parts of Serbia is much smaller.Based on the results, it can be concluded that the event should be more promoted in the whole of Serbia.

Through the research, we intended to determine the perception of Dolovo strudel as a recognizable brand. That was our criterion (dependent) variable, whereas we took two questions referring to the attractiveness of the event and the recognizability of the Dolovo strudel as predictor (independent) variables. The criterion variable is applied through question: 'Is the Dolovo strudel a recognizable brand?'coded as 'dummy variable' (categorical): 1 - yes and 0 - no. The first predictor variable the attractiveness of the event has been applied using question: 'Do you think that this gastronomic event is attractive?', and the second the recognizability of the Dolovo strudel using question: 'Is the Dolovo strudel the most delicious Banat cake?'. Both predictor variables are dichotomous coded as dummy variable: 1 - yes and $0-$ no. The result is statistically significant; $\chi^{2}(2)=34.92, \mathrm{p}=0.00$; which shows that the predictor variables significantly contribute to the interpretation of the criterion variable - the perception of the Dolovo strudel as a recognizable brand. The predictor variables interpret between 20.8 (Cox and Snell $\mathrm{R}^{2}$ ) and $53.6\left(\right.$ NagelkerkeR $^{2}$ ) the variances of the criterion variable.

Table 2. Perception of the Dolovo strudel as a brand

\begin{tabular}{|c|c|c|c|c|c|c|}
\hline & \multirow[b]{2}{*}{ B } & \multirow[b]{2}{*}{ S.E. } & \multirow[b]{2}{*}{ p. } & \multirow[b]{2}{*}{$\operatorname{Exp}(B)$} & \multicolumn{2}{|c|}{95 confidence interval } \\
\hline & & & & & $\begin{array}{c}\text { Lower } \\
\text { endpoint }\end{array}$ & $\begin{array}{l}\text { Upper } \\
\text { endpoint }\end{array}$ \\
\hline $\begin{array}{l}\text { Is the Dolovo strudel the most } \\
\text { delicious Banat cake? (yes) }\end{array}$ & 3.066 & 0.943 & 0.001 & 21.451 & 3.377 & 136.261 \\
\hline $\begin{array}{l}\text { Do you think that this } \\
\text { gastronomic event is attractive? } \\
\text { (yes) }\end{array}$ & 3.329 & 0.972 & 0.001 & 27.910 & 4.150 & 187.713 \\
\hline Constant & -1.644 & 0.916 & 0.073 & .193 & & \\
\hline
\end{tabular}

Source: Author's calculation based on SPSS 22.0

Table number 2 shows that both predictor variables significantly contribute to the recognition of the Dolovo strudel brand, $\mathrm{p}<0.05$. The respondents who consider the Dolovo strudel the most delicious Banat cake are more likely to accept it as a brand $(\mathrm{OR}=21.45$; $95 \mathrm{CI}=3.38-136.26$; $\mathrm{p}=0.00$ ) compared to those who do not think that the Dolovo strudel is the most delicious cake of Banat. The respondents who think that the Dolovo Strudel Festival is attractive are more likely to accept it as a brand $(\mathrm{OR}=27.91 ; 95 \mathrm{CI}=4.15-187.71 ; \mathrm{p}=0.00)$ compared to the respondents who do not think the festival is attractive. The competitive part of the festival is the evaluation of the strudels in different categories by the expert competition jury, followed by the announcement of the best strudels. It is very interesting for the members of associations as well as for the visitors, as they find out which strudels are really good.

The Fisher exact test was applied to recognize the differences between the respondents who consider the Dolovo strudel a recognizable brand and the respondents who do not share that opinion. 
Table 3. Differences in terms of recognizability of the Dolovo strudel brand

\begin{tabular}{|c|c|c|c|c|c|c|c|c|}
\hline & \multicolumn{4}{|c|}{$\begin{array}{l}\text { Is the Dolovo strudel a } \\
\text { recognizable brand? }\end{array}$} & \multicolumn{2}{|c|}{$\mathrm{N}$} & \multirow[b]{3}{*}{$\mathrm{p}$} \\
\hline & & \multicolumn{2}{|c|}{ no } & \multicolumn{2}{|c|}{ yes } & & & \\
\hline & & f & $\%$ & f & $\%$ & f & $\%$ & \\
\hline \multirow{2}{*}{ Gender } & male & 2 & 20.0 & 27 & 19.3 & 29 & 19.3 & 0.612 \\
\hline & female & 8 & 80.0 & 113 & 80.7 & 121 & 80.7 & \\
\hline \multirow{3}{*}{ Age } & up to 35 & 1 & 10.0 & 26 & 18.6 & 27 & 18.0 & \multirow{3}{*}{0.515} \\
\hline & 36 to 50 & 2 & 20.0 & 36 & 25.7 & 38 & 25.3 & \\
\hline & over 50 & 7 & 70.0 & 78 & 55.7 & 85 & 56.7 & \\
\hline \multirow{3}{*}{ Level of education } & $\begin{array}{l}\text { primary, high } \\
\text { school }\end{array}$ & 6 & 60.0 & 88 & 62.9 & 94 & 62.7 & \multirow{3}{*}{0.552} \\
\hline & \begin{tabular}{|l|} 
college, \\
university
\end{tabular} & 3 & 30.0 & 44 & 31.4 & 47 & 31.3 & \\
\hline & $\begin{array}{l}\text { Master's degree, } \\
\text { PhD } \\
\end{array}$ & 1 & 10.0 & 8 & 5.7 & 9 & 6.0 & \\
\hline \multirow{2}{*}{$\begin{array}{l}\text { Is this event sufficiently } \\
\text { promoted in your opinion? }\end{array}$} & no & 4 & 40.0 & 26 & 18.6 & 30 & 20.0 & \multirow{2}{*}{0.144} \\
\hline & yes & 6 & 60.0 & 114 & 81.4 & 120 & 80.0 & \\
\hline \multirow{3}{*}{$\begin{array}{l}\text { How did you learn about this } \\
\text { event? }\end{array}$} & TV & 5 & 50.0 & 23 & 16.4 & 28 & 18.7 & \multirow{3}{*}{0.075} \\
\hline & \begin{tabular}{|l|} 
Internet \\
\end{tabular} & 1 & 10.0 & 19 & 13.6 & 20 & 13.3 & \\
\hline & $\begin{array}{l}\text { friends' } \\
\text { recommendation }\end{array}$ & 4 & 40.0 & 98 & 70.0 & 102 & 68.0 & \\
\hline \multirow{2}{*}{$\begin{array}{l}\text { In your opinion, is this } \\
\text { gastronomic event authentic? }\end{array}$} & no & 2 & 20.0 & 3 & 2.1 & 5 & 3.3 & \multirow{2}{*}{0.036} \\
\hline & yes & 8 & 80.0 & 137 & 97.9 & 145 & 96.7 & \\
\hline \multirow{3}{*}{$\begin{array}{l}\text { What is authentic in this } \\
\text { event? }\end{array}$} & \begin{tabular}{|l} 
strudels \\
\end{tabular} & 7 & 70.0 & 97 & 69.3 & 104 & 69.3 & \multirow{3}{*}{0.634} \\
\hline & \begin{tabular}{|l} 
program of the \\
event
\end{tabular} & 2 & 20.0 & 36 & 25.7 & 38 & 25.3 & \\
\hline & competition & 1 & 10.0 & 7 & 5.0 & 8 & 5.3 & \\
\hline \multirow{2}{*}{$\begin{array}{l}\text { Have you tried Dolovo } \\
\text { strudel before? }\end{array}$} & no & 2 & 20.0 & 27 & 19.3 & 29 & 19.3 & \multirow{2}{*}{0.612} \\
\hline & yes & 8 & 80.0 & 113 & 80.7 & 121 & 80.7 & \\
\hline \multirow{5}{*}{$\begin{array}{l}\text { Which strudel do you like } \\
\text { tasting most? }\end{array}$} & \begin{tabular}{|l|}
$\begin{array}{l}\text { poppyseed } \\
\text { strudel }\end{array}$ \\
\end{tabular} & 8 & 80.0 & 82 & 58.6 & 90 & 60.0 & \multirow{5}{*}{0.317} \\
\hline & walnut strudel & 1 & 10.0 & 37 & 26.4 & 38 & 25.3 & \\
\hline & carob strudel & 1 & 10.0 & 9 & 6.4 & 10 & 6.7 & \\
\hline & \begin{tabular}{|l|}
$\begin{array}{l}\text { fruit filling } \\
\text { strudel }\end{array}$ \\
\end{tabular} & 0 & 0.0 & 9 & 6.4 & 9 & 6.0 & \\
\hline & \begin{tabular}{|l|} 
strudel with \\
savory filling
\end{tabular} & 0 & 0.0 & 3 & 2.1 & 3 & 2.0 & \\
\hline \multirow{2}{*}{$\begin{array}{l}\text { Is the Dolovo strudel the } \\
\text { most delicious Banat cake? }\end{array}$} & no & 8 & 80.0 & 17 & 12.1 & 25 & 16.7 & \multirow{2}{*}{0.000} \\
\hline & yes & 2 & 20.0 & 123 & 87.9 & 125 & 83.3 & \\
\hline \multirow{2}{*}{$\begin{array}{l}\text { Is the cultural and artistic } \\
\text { program of this event well } \\
\text { designed? }\end{array}$} & no & 1 & 10.0 & 2 & 1.4 & 3 & 2.0 & \multirow[b]{2}{*}{0.188} \\
\hline & yes & 9 & 90.0 & 138 & 98.6 & 147 & 98.0 & \\
\hline Are you at this event as a & Association & 5 & 50.0 & 81 & 57.9 & 86 & 57.3 & \\
\hline $\begin{array}{l}\text { visitor or a member of an } \\
\text { association? }\end{array}$ & Visitor & 5 & 50.0 & 59 & 42.1 & 64 & 42.7 & 0.745 \\
\hline Is this gastronomic event & no & 6 & 60.0 & 5 & 3.6 & 11 & 7.3 & 0000 \\
\hline attractive? & yes & 4 & 40.0 & 135 & 96.4 & 139 & 92.7 & \\
\hline
\end{tabular}


Economics of Agriculture, Year 68, No. 3, 2021, (pp. 659-674), Belgrade

\begin{tabular}{|c|c|c|c|c|c|c|c|c|}
\hline \multirow{2}{*}{$\begin{array}{l}\text { Do you like the idea of a } \\
\text { collective wedding in this } \\
\text { event? }\end{array}$} & no & 1 & 10.0 & 7 & 5.0 & 8 & 5.3 & \multirow[b]{2}{*}{0.432} \\
\hline & yes & 9 & 90.0 & 133 & 95.0 & 142 & 94.7 & \\
\hline \multirow{3}{*}{$\begin{array}{l}\text { What are you taking as a } \\
\text { souvenir from this event? }\end{array}$} & \begin{tabular}{|l|} 
strudels \\
\end{tabular} & 4 & 40.0 & 80 & 57.1 & 84 & 56.0 & \multirow{3}{*}{0.084} \\
\hline & handicrafts & 0 & 0.0 & 16 & 11.4 & 16 & 10.7 & \\
\hline & memories & 6 & 60.0 & 44 & 31.4 & 50 & 33.3 & \\
\hline \multirow{3}{*}{$\begin{array}{l}\text { The reason you visited this } \\
\text { gastronomic event? }\end{array}$} & socializing & 7 & 70.0 & 81 & 57.9 & 88 & 58.7 & \multirow{3}{*}{0.525} \\
\hline & strudels & 1 & 10.0 & 40 & 28.6 & 41 & 27.3 & \\
\hline & curiosity & 2 & 20.0 & 19 & 13.6 & 21 & 14.0 & \\
\hline
\end{tabular}

Source: Author's calculation based on SPSS 22.0

The findings of the Fisher test show that the respondents who think that the Dolovo strudel is a recognizable brand considerably differ from the respondents who do not think so, according to how they answered the question: 'In your opinion, is this gastronomic event authentic?'; $p=0.04$. The respondents who consider the Dolovo strudel a recognizable brand also consider this event authentic (94.5\%). Answering the question 'What is authentic in this event?' $69.3 \%$ said 'strudel', followed by $25.3 \%$ answering 'program of the event', whereas only $5.3 \%$ 'competition'. This indicates that strudels are indeed the brand of this event, in terms of authenticity for the respondents.

Answering the question 'Is this event sufficiently promoted, in your opinion?',80\% of the respondents said YES, whereas only $20 \%$ said NO. That is a clear indication of a high level of the promotion of this event. It is interesting to note that, when asked 'How did you learn about this event?', $68 \%$ of the respondents said they were informed through friends' recommendations, followed by $18.7 \%$ who heard about it on TV, and only $13.3 \%$ heard about it from the Internet. Friends' recommendations and personal experience of those who have already visited this event and formed a positive attitude and perception are the best recommendation for the new visitors.

The findings of the Fisher test show that the respondents who think that the Dolovo strudel is a recognizable brand considerably differ from those who do not share the same opinion, according to how they answered the question: 'Is the Dolovo Strudel the most delicious Banat cake?'; $p=0.00$. The respondents who consider the Dolovo strudel a recognizable brand mostly think that the Dolovo strudel is the most delicious cake of Banat (87.9\%). Replying to the question 'Have you tried the Dolovo strudel before?', $80.7 \%$ of the respondents said YES, and 19.3\% said NO. The respondents who said YES had already visited this event before, and those who said NO came for the first time and had not had the chance to try it before. 'Which strudel do you like tasting most?' has provided us with the answer which kind of strudel is the most popular and in greatest demand. The poppyseed strudel is the most popular, which was confirmed by $60 \%$ of the respondents, followed by walnut strudel according to $25.3 \%$ of the respondents, whereas the remaining three types of strudel attracted considerably lower interest among the respondents, and they are carob strudel $6.7 \%$, fruit filling strudel $6.0 \%$ and strudel with savory filling $2.0 \%$. 
The findings of the Fisher test show that the respondents who think that the Dolovo strudel is a recognizable brand considerably differ from those who are not ofthe same opinion, according to how they answered the question: 'Is this gastronomic event attractive?'; $\mathrm{p}=0.00$. Those who think that the Dolovo strudel is a recognizable brand mostly like the competitive part of the event (96.4\%). Answering the question 'Is the cultural and artistic program of this event well designed?', $98 \%$ of the respondents said YES, and only $2.0 \%$ NO. This is an indication that the program of the event(cultural-artistic, exhibitions, sales, competition) is of great importance for this event. The respondents in the survey were members of various associations (86 - 57.3\%) and visitors (64 $42.7 \%$ ), with the aim to receive the answers from two different standpoints. The novelty at this event was the organization of a collective wedding, and answering the question 'Do you like the idea of a collective wedding in this event?' $94.7 \%$ of the respondents said YES, and only 5.3\% said NO. Therefore, it can be concluded that the visitors liked the idea, as the newlyweds tasted the Dolovo strudel as their wedding cake after the wedding ceremony. When asked 'The reason you visited this gastronomic event?', the respondents answered that it was mostly in order to socialize $58.7 \%$, considering the fact that in such gastronomic events the members of associations and the visitors socialize and exchange experience; $27.3 \%$ said the reason were strudels, and $14.0 \%$ said that the reason for coming was curiosity as they had heard of this event. Replying the question 'What are you taking as a souvenir from this event?' the most common answer was 'strudels' (56.0\%), followed by 'memories' (33.3\%), and 'handicraft' (10.7\%).

The results of the survey show that the gastronomic event Dolovo Strudel Festival is for the time being recognizable mostly on the local level, as there are not many visitors from other parts of Serbia. Through a better promotion using Internet presentations, TV shows, tourist organizations, the current situation can be improved and a larger number of participants from different associations as well as more visitors can be attracted. The Dolovo strudel is certainly a recognizable brand of this event and it is indeed authentic and well accepted by visitors, which is clearly indicated by the results of this survey. However, this should be used as a good basis for further development and improvement of this event, because in addition to local and regional, it can also have international significance from the aspect of gastronomic tourism.

\section{Conclusions}

Gastronomic events represent an important incentive for tourists to visit a particular destination. Many gastronomic events are of local character, such as the Dolovo Strudel Festival, but by fostering and preserving the traditional specialties they can have a significant role in tourist traffic. In addition to attracting tourists to the place where an event is taking place, gastronomic events can also create a distinctive image and brand of the destination, which can further motivate numerous tourists. Events are of great importance for associations trying to preserve authentic food and beverages, but also for all other catering facilities, as these events can attract a large number of locals, as well as tourists, and thus have significant economic implications. 
The results of the survey show that this Festival a unique gastronomic event. The Dolovo strudel as an authentic brand of this event attracts the attention of a large number of visitors, but at the local level for now. The women's association 'Dolovke' should intensify the promotion and affirmation of this event and its brand strudel, not only in the city of Pančevo and the surrounding area, but also in other parts of Serbia. It is advisable to make more use of tourist brochures and gastronomic guides, with a detailed description and photographs from the event, as it would attract a larger number of visitors to this gastronomic event.Furthermore, it is necessary to pay more attention to practical souvenirs made in the form of edible gifts, which can be taken from the event and present in a great way the event and the region to the potential visitors.For the purpose of future research and for potential tourists, it is necessary to improve the editing of the data on the websites of tourist organizations, as they are not regularly updated and therefore create confusion. Improved promotion and the arrival of a larger number of visitors can have significant economic impact on the city of Pančevobecause, in addition to attending the event, the visitors could come to see other sights, catering facilities, as well as other interesting sites in this tourist destination. Moreover, the tourist organizations of Serbia, Vojvodina and the city of Pančevo could design a tourist route, which would include the visit to Dolovo Strudel Festival and offer the domestic and foreign tourists a longer stay in this tourist destination. A better promotion and a more complex tourist content would certainly enable the Dolovo Strudel Festival to enrich the gastronomic offer of the city of Pančevo as a tourist destination, and at the same time the overall gastronomic offer of Vojvodina and Serbia.

\section{Conflict of interests}

The authors declare no conflict of interest.

\section{References}

1. Бјељац, Ж. \& Ћурчић, Н. (2007), Туристичке манифестације на простору Западног Поморавља. Гласник Српског географског друштва, 87(2), $225-$ 240. [In English: Bjeljac, Ž. \& Ćurčić, N. (2007), Tourist events in Western Pomoravlje. Bulletin of the Serbian Geographical Society, 87(2), 225-240.]

2. Backman, K, Backman, S., Uysal, M. \& Mohr Sunshine, K. (1995), Event tourism An examination of motivations and activities, Festival Management \& Event Tourism, 3 (1), pp. 15-24.

3. Čavić, S. \& Stojanović, D. (2018), Gastronomske manifestacije kao vid očuvanja autentičnih jela, poslastica i vina u Vojvodini, Znanstveno stručni skup s međunarodnim sudjelovanjem "130 godina organiziranoga vinogradarstva $i$ vinarstva u Bosni i Hercegovini”, Federalni agromediteranski zavod Mostar, Agronomski i prehrambeno-tehnološki fakultet Sveučilišta u Mostaru. [In English: Čavić, S. \& Stojanović, D. (2018), Gastronomic events as a form of preserving authentic dishes, sweets and wines in Vojvodina, Scientific and expert meeting with international participation '130 years of organized viticulture and 
winemaking in Bosnia and Herzegovina', Federal Agro-Mediterranean Institute Mostar, Faculty of Agriculture and Food technology University of Mostar]

4. Čavić, S. \& Mandarić, M. (2021), Authenticity of gastronomic events as a function of branding a destination, Hotel and Tourism Management, 9 (1) 89-101, http:// doi.org/10.5937/menhottur2101089C

5. Доловачка штрудлијада [In English: Dolovo Strudel Festival], Retrieved from https://www.manifestacije.com (September 01,2020.)

6. Fox, R. (2007), Reinventing the gastronomic identity of Croatian tourist destinations, Hospitality Management, 26, pp. 546-59. https://doi.org/10.1016/j. ijhm.2006.03.001

7. Getz, D. \& Wicks, J. (1993), Editorial. Festival Management \& Event Tourism, 1(1), pp. 1-3.

8. Hall, C.M. \& Mitchell, R. (1998), We are what we eat: food, tourism and globalisation, paper presented at Innovative Approaches to Culture and Tourism, ATLAS conference, 22-24 October 1998, Rethymnon, Crete

9. Hall, C.M., Sharples, E., Mitchell, R., Cambourne, B. \& Macionis, N. (eds.) (2003), Food Tourism Around the World: Development, Management and Markets . Butterworth- Heinemann, Oxford

10. Јовановић, В. (2015), Тематски туризам. Београд: Универзитет Сингидунум [In English: Jovanović, V. (2015), Thematic tourism. Belgrade: Singidunum University]

11. Jojić Novaković, Đ. \& Mandarić, M. (2019), Do events contribute to the brand of Novi Sad? A millennials' perspective, Hotel and Tourism Management, 7(1), 47-59. https://doi.org/10.1016/j.ijhm.2006.03.001

12. Long, L.M. (2004), Culinary Tourism. The University Press of Kentucky: Lexington.

13. Leech, N., Barrett, K. \& Morgan, G. (2005), SPSS for Intermediate Statistics: Use and Interpretation. Second Edition. New Jersey: LAWRENCE ERLBAUM ASSOCIATES, PUBLISHERS

14. Мандарић, М. (2016), Стратегијски бренд менаимент. Врњачка Бања: Факултет за хотелијерство и туризам у Врњачкој Бањи. [In English: Mandarić, M. (2016), Strategic brand management. Vrnjačka Banja: Faculty of Hotel Management and Tourism in Vrnjačka Banja.]

15. Mandarić, M., Milićević, S. \& Sekulić, D. (2017), Traditional values in the function of promotion of Šmadija and Pomoravlje as rural tourism destinations, Ekonomika poljoprivrede, Economics of Agriculture (64) 2., 787-803. https://doi. org/10.1016/j.ijhm.2006.03.001 
16. Мандарић,М.\& Стаменковић,И.(2017), Истраживањезначаја манифестација за развој и брендирање града Ниша као туристичке дестинације, XиT МЕНАЦМЕНТ, Менацмент у хотелијерству и туризму, 5(1) 64 -74. [In English: Mandarić, M. \& Stamenković, I. (2017), Exploring the significance of events for the development and branding of the city of Niš as a tourist destination, H\&T MANAGEMENT, Hotel Management and Mnagement in Tourism, 5(1) 64 $-74]$

17. Perić, G. \& Mandarić, M. (2020), Challenges in tourist destination branding in Serbia: The case of Prolom Banja, Ekonomika preduzeća, Serbian Association of Economists Journal of Business Economics and Management, 442-456. https:// doi.org/10.5937/EKOPRE2006442P

18. Pallant, J. (2011), SPSS Survival manual, $4^{\text {rd }}$ edition. Australia: Allen \& Unwin

19. Stanišić, T., Kostić, M. \& Mišeljić, M. (2018), Gastronomic manifestations as a factor of improvement of Serbia's tourism offer, Ekonomika poljoprivrede, Economics of Agriculture (65) 1., 111-124. https://doi.org/10.5937/ $\underline{\text { ekoPolj1801111S }}$

20. Стевановић, С. \& Малинић, В. (2016), Значај манифестација за развој туризма у Београду, ХиТ МЕНАЦМЕНТ, Менаимент у хотелијерству и туризму, 4(1), 53-63. [In English: Stevanović, S. \& Malinić, V. (2016), Significance of events for the development of tourism in Belgrade, H\&T MANAGEMENT, Hotel Management and Mnagement in Tourism, 4(1), 53-63.]

21. Стојановић, Д. (2017), Гастрономске манифестације источне Србије као фактор развоја туризма, Хотел Линк, Висока хотелијерска школа струковних студија Београд, 192-201 [In English: Stojanović, D. (2017), Gastronomic events of eastern Serbia as a factor in the development of tourism, Hotel Link, College of Hotel Management Belgrade, 192-201]

22. Stojanović, D., Čavić, S. \& Stojanović, Đ. (2018), Importance of gastronomic manifestations of Eastern Serbia for tourism development, The 2nd International Conference on Management, Engineering and Environment, ICMNEE 2018.

23. Stojanović, D., Vukić, M., Vukić, K. \& Jovanović, V. (2020), Satisfaction of visitors with food offer at gastronomic festivals in rural areas, Ekonomika poljoprivrede, Economics of Agriculture (67) 2., 523-536. https://doi.org/10.5937/ ekoPolj2002523S

24. Стратегија развоја туризма Републике Србије за период 2016-2025. Министарство трговине, туризма и телекомуникација, [In English: Tourism Development Strategy of the Republic of Serbia for the Period 2016-2025. Ministry of Trade, Tourism and Telecommunications], Retrieved from http://mtt. gov.rs/download/3/strategija.pdf (September 05,2018.)

25. Sheskin, D. (2004), Handbook of Parametric and Nonparametric Statistical Procedures, $3^{\text {rd }}$ edition. United States of America: Library of Congres 
26. Вељковић, С. (2010), Бренд менаимент у савременим тржишним условима. Београд: Центар за издавачку делатност Економског факултета у Београду. [In English: Veljković, S. (2010), Brand management in modern market conditions. Belgrade: Publishing Center of the Faculty of Economics in Belgrade.]

27. Wargenau, A \& Che, D. (2006), Wine tourism development and marketing strategies in Southwest Michigan. International Journal of Wine Marketing, 18(1), pp. 45-60. https://doi.org/10.1108/09547540610657678

28. Завод за интелектуалну својину Републике Србије [In English: Intellectual Property Office of the Republic of Serbia], Retrieved from http://reg.zis.gov.rs/

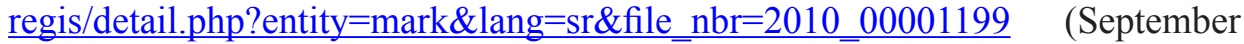
20,2020 ) 